Vol. 5, No. 2, 2020

\title{
ECOLOGICAL PROBLEMS OF ENTERPRISES OF ALCOHOL INDUSTRY
}

\author{
Marianna Havryshko, Olena Popovych, Halyna Yaremko
}

\author{
Lviv Polytechnic National University, \\ 12, S. Bandery Str., Lviv, 79013, Ukraine \\ marianna.i.havryshko@lpnu.ua,lpolenaeko@yahoo.com, halynayaremko@gmail.com
}

https://doi.org/10.23939/ep2020.02.107

Received: 10.05 .2020

(C) Havryshko M., Popovych O., Yaremko H., 2020

\begin{abstract}
The issue of industrial water treatment and food waste disposal is particularly relevant, especially for the alcohol industry. The problem of wastewater treatment and waste accumulation in the process of alcohol production is due to high chemical and biological oxygen demand, specific colour and odour, a large number of suspended substances, low $\mathrm{pH}$. Therefore, the choice of promising wastewater treatment technologies is of paramount importance to ensure the ecological safety of the environment. The purpose of the paper is 1) to analyze the state of the alcohol industry in Ukraine in recent years, and methods of its waste disposal; 2) to investigate and determine effective methods of waste disposal in the alcohol industry.
\end{abstract}

Key words: alcohol industry, wastes, wastewater, efficiency, biogas, biofuel, environmental safety.

\section{Introduction}

At present, the gradual introduction of the balanced use of natural resources concepts and ecologically safe, energy-efficient development of industrial and production enterprises is taking place. The major purpose of their implementation is to ensure that the human needs for resources do not conflict with the priorities of environmental protection and human health.

Therefore, the capacity growth of the alcohol industry at the present stage of the food industry development leads to the formation of enormous volumes of wastewater from the production process (1 litre of ethanol is accompanied by the formation of 12-14 litres of wastewater).

Due to the unsatisfactory current state of treatment facilities and low efficiency of technological processes of treatment and utilization in Ukraine, wastewater is one of the main factors of hydrosphere pollution, and sludge being one of the significant factors of lithosphere pollution, which in turn creates a number of environmental risks.

In the conditions of constant deterioration of the environment, improving the quality of wastewater treatment before discharge and improving the organoleptic and other characteristics of the formed sediments, before their disposal is an urgent task today.

Thus, there appears a scientific and applied problem of creating new and improving existing environmentally friendly technological processes of treatment and disposal of industrial and municipal wastewater, which will ensure the rational use of available renewable resources.

Theoretical, practical, and methodological issues related to the use of food industry waste and their social and economic consequences are the subject of scientific interests of many domestic and foreign scholars [1]. Examining the economic aspects of the waste impact consequences on the world's natural resources, T. Zinchuk notes that all countries of the world, regardless of the level of their resources, feel the same negative impact of human production activities on the ecological balance, environment and natural resources, the state of which deteriorates dramatically and leads to the gradual loss of food security [2].

Problems of rational use of renewable resources, creation of new and improvement of existing ecologically safe technological processes of purification and utilization of industrial and municipal sewage, are reflected in the works of S. Shamansky. In particular, according to his assertion, treatment plants are a potential source of additional raw materials, which are now considered waste, as well as non-traditional energy sources, the potential of which is not fully used, primarily due to shortcomings of modern wastewater treatment technologies [3]. 
Current world trends in the use of alcohol products allow us to solve some interrelated problems of social and environmental nature. Thus, recently, technologies aimed at improving the quality of fuel with the use of high-octane oxygen-containing additives to gasoline have become increasingly important, which allows to include blended gasoline to biofuels. Solving this problem will simultaneously solve some problems in consumer industries, namely energy and refining industries. Also, the use of high-octane oxygencontaining additives to gasoline in the production of biofuels will significantly improve the environmental situation, especially in the cities [4].

Ukraine annually consumes about 200 million tons of fuel and energy resources and is an energydeficient country because it covers its energy needs by about $53 \%$ and imports $75 \%$ of the required volume of natural gas and $85 \%$ of crude oil and petroleum products. Such a structure of the fuel and energy complex is economically impractical, creates the dependence of Ukraine's economy on oil and gas exporting countries, and is a threat to its energy and national security. It is also known that, based on the assessment of global oil reserves, the era of its depletion is approaching. Naturally, this will significantly exacerbate the energy problems of most countries. Therefore, the world economy pays great attention to the use as an energy source of renewable raw materials - ethyl alcohol as biofuel. Biofuel, which includes high-octane oxygencontaining additives to gasoline, is the energy resource of biological origin, the major feature of which is its renewable ability [5].

The goals of the article are the analysis of the current state and the main environmental aspects of the alcohol industry development, including Ukraine as well as identifying the promising areas of utilization and the use of waste from the alcohol industry of Ukraine as secondary raw materials, on the example of Ukrspyrt State Enterprise. The aim of the study is to find the effective methods of utilization and the levers of state regulation that can direct the enterprises of the alcohol industry to energy efficiency and implementation of socially important environmental and economic tasks.

\section{Experimental part}

The alcohol industry is focused on raw materials. Alcohol is used in more than 150 industries. The raw material base for alcohol production is molasses, defective sugar, grain, potatoes. Usually, distilleries are located in small settlements. Most alcohol in Ukraine is produced from waste from sugar industry.

The alcohol industry of Ukraine includes 79 stateowned production sites, including 41 (only 12 of which operate) are the part of Ukrspyrt State Enterprise, a leading producer of food alcohol. The total loss of enterprises that form the alcohol industry in 2018 reached UAH 25.7 million, only 8 of the 21 state-owned enterprises got a profit, and 11 enterprises are in bankruptcy [6].

The total production capacity of Ukrspyrt State Enterprise is over 36 million decalitres per year. In January 2020, Ukrspyrt State Enterprise officially sold 440, 60 thousand decalitres of alcohol. At the same time, for the same period last year, only 255, 17 thousand decalitres were sold [7], which will proportionally lead to a decrease in the number of effluents by almost twice.

Vodka and alcoholic beverages make up the largest share in the structure of sales of ethyl rectified alcohol by distilleries [7].

In terms of raw material consumption, alcohol production is the largest biotechnological production in the world, and ethanol is the third largest in terms of gross product value.

Varieties of alcohol (ethyl alcohol, technical bioethanol, food alcohol, technical alcohol, medical alcohol, alcoholic beverages) depend on the type of raw material, yeast strains, quality of distillation, degree of dilution, denaturation, etc.

Today, all fuel ethanol is produced biotechnologically by fermentation (yeast) or sugars (sugar cane), or starchcontaining raw materials (mostly corn).

The main wastes of alcohol production, depending on the substrate, are post-alcohol molasses, post-alcohol grain and post-yeast molasses bard with $\mathrm{pH}=4.5-7.0$, which after evaporation is disposed of for feed, fertilizer, feed additive, feed yeast, production of drugs (acidin, glutamate), etc. Per 1,000 dal of alcohol, $140 \mathrm{~m}^{3}$ of grain bard is formed, and 12,000 dal of molasses bard, on which fodder sugarmycetes are produces.

Production of 1 litre of ethanol is accompanied by the formation of 12-14 litres of wastewater. [8].

According to the data given in the research of T. Melnychenko, V. Kadoshnikov, K. Zhebrovska, O. Petrenko, O. Puhach "Introduction of advanced technologies of waste utilization at the objects of alcohol industry - a guarantee of environmental protection" at different enterprises, the composition and amount of wastewater differ significantly. Table 1 shows the characteristics of wastewater from alcohol enterprises, which use molasses as raw material [9].

Molasses post-alcoholic bard contains a large number of nutrients (in terms of dry reducing substances (4-6 \%), colloidal Dumansky (13-15\%), potassium (8.5-13\%), sodium (1.3-2.5\%), calcium (0.5-2.5\%), sulfate ions (0.6-4.6\%), chloride ions (0.9-3.0\%).

Traditionally, fresh bard in its natural form was used for fattening cattle on collective farms and fattening farms. Glycerin (only at Lokhvytsya 
Distillery), glutamic acid and monosodium glutamate, betaine, medical acid, feed yeast, feed concentrate of vitamin B12 (KMB-12) were obtained from it by processing [9].

Table 1

Characteristics of wastewater from alcohol enterprises, which use molasses as raw material

\begin{tabular}{|l|c|c|c|c|c|c|}
\hline \multirow{2}{*}{ Indicators } & \multicolumn{4}{c|}{ Category of wastewater } & \multirow{2}{*}{ Primary bard } & \multirow{2}{*}{ Secondary bard } \\
\cline { 2 - 5 } & first & second & fourth & fifth & & \\
\hline Temperature, $\mathrm{C}$ & $30-60$ & $20-100$ & $80-100$ & $20-90$ & $95-98$ & $25-30$ \\
\hline Odor, points & $0-3$ & $3-5$ & $4-7$ & $3-64$ & 5.0 & 5.0 \\
\hline $\mathrm{pH}$ & $7.0-8.0$ & $8-12$ & $4.4-6.4$ & $5.5-6.2$ & $5.0-5.5$ & $4.5-5.0$ \\
\hline Transparency, sm & $12-30$ & $10-25$ & $15-25$ & $0-2$ & 0 & 0 \\
\hline Dry residue, g/l & $0.35-0$ & $13-20$ & $0.3-0.6$ & $0.45-10.0$ & $70-85$ & $50-65$ \\
\hline $\mathrm{COD}_{\mathrm{mg} \mathrm{O}} / \mathrm{l}$ & $5-40$ & $10-40$ & $60-350$ & $1000-4000$ & $49000-66900$ & $20000-48000$ \\
\hline $\mathrm{BOD}_{20}, \mathrm{mg} \mathrm{O}_{2} / \mathrm{l}$ & $5-12$ & $5-80$ & $180-300$ & $950-4500$ & $44000-59000$ & $18000-40000$ \\
\hline $\mathrm{BOD}_{5}, \mathrm{mg} \mathrm{O} / \mathrm{l}$ & $2-10$ & $2-40$ & $100-2500$ & $600-3700$ & $29000-48000$ & $15500-29900$ \\
\hline Nitrogen total, mg/l & - & - & - & - & $2500-3860$ & $940-2500$ \\
\hline Volatile acids, $\mathrm{mg} / \mathrm{l}$ & - & - & - & - & $2300-3900$ & $300-720$ \\
\hline
\end{tabular}

Characterization of wastewater is necessary to determine the method of treatment, the possibility of discharge into reservoirs, the presence of valuable or toxic impurities. The methods for wastewater treatment, which is later submitted for further treatment in compliance with all water quality requirements provided by law, are determined then.

The composition of wastewater and its properties are evaluated by the results of sanitary and chemical analysis, which consists of a number of physical, physicochemical and sanitary-bacteriological determinations.

The great diversity of the composition of effluents and the impossibility of analyzing each of the polluting components leads to the need to choose such indicators that would describe certain properties of water without the identification of individual substances. Such indicators are called group (total). Complete sanitary and chemical analysis includes the characteristics of the following indicators: temperature, color, odor, transparency, suspended solids by volume and mass, permanganate oxidation, chemical oxygen demand (COD), biochemical oxygen demand (BOD), $\mathrm{pH}$, dry residue, dense residue and puncture losses, surfactants, petroleum products, dissolved oxygen, microbial count, Escherichia coli bacteria (ECD), helminth eggs. nitrogen (total, ammonium, nitrite, nitrate), phosphates, chlorides, sulfates, heavy metals and other toxic elements.

In addition to these indicators, the mandatory tests of complete sanitary and chemical analysis at municipal treatment plants include the determination of specific impurities entering the drainage system of settlements from industrial enterprises.

Requirements to the composition and properties of wastewater of enterprises for their safe disposal by the sewerage network according to appendix 1 to the "Rules of wastewater acceptance of enterprises in communal and departmental sewerage systems of settlements of Ukraine", approved by the order of the State Construction Committee of Ukraine of February 19, 2002 N 37 [10].

In Ukraine, the technology of wastewater treatment of distilleries, developed by the Department of Ecology of UkrNDIspyrtbioprod, provides:

- purification of Lutheran waters at bio-treatment plants and return to production;

- cleaning of post-alcoholic grain bard by centrifugation or vacuum filtration to obtain $25 \%$ of the pellet, which is dried on a drum or disk dryer with a yield of 7 tons of protein feed per 1000 dal of alcohol;

- cooling of the liquid fraction (100 tons of filtrate per 1000 dal of alcohol) to $35-45{ }^{\circ} \mathrm{C}$ and the implementation of two-stage anaerobic-aerobic purification to obtain biogas [8].

Fig. 1 shows the basic technological scheme of the most effective mechanical and biological treatment of industrial and domestic sewage to pure ecologically safe, biologically high-grade water. For mechanical treatment, wastewater 3 passes through the grids 4, where coarse mechanical impurities are retained, then through the sand trap 5, where the sand is separated, and finally enters the primary settling tanks 6 , where under gravity everything heavier than water settles to the bottom. After that, the water is pumped into the methane tanks 1 for fermentation, with the release of methane gas, and after a full period is released on sludge sites with drainage 2 , and everything lighter than water rises to the water surface, where it is collected by special devices in the hopper and also goes to the methane tank. At all the stages of water passing through treatment plants, biological processes take place in it. But the most noticeable biological wastewater treatment occurs at the second biological stage. In a bioreactor with a biofilm, the biomass of aquatic organisms 7 , which increases 
during water purification, is separated in secondary settling tanks 8 , from here it is fed either to methane tanks 1 or to sludge sites 2 . Water purification consists of its complete disinfection, that is, in the destruction of epidemically dangerous organisms and vibrios in the water. For this purpose chlorination, irradiation with ultraviolet light, and less often ozonation are used. When treating treated wastewater with chlorine, it is incubated for $20-30 \mathrm{~min}$ in contact tanks 10, and then discharged into open water. Some scientists consider chlorination of wastewater absolutely unacceptable. Therefore, a reliable scheme has been developed, which includes processes of treatment with flocculants and coagulants in the apparatus 11, settling 12, filtration through sand 13, and finally through activated carbon 14 . The sludge in this scheme is concentrated on filters 15 and sent to the landfill.

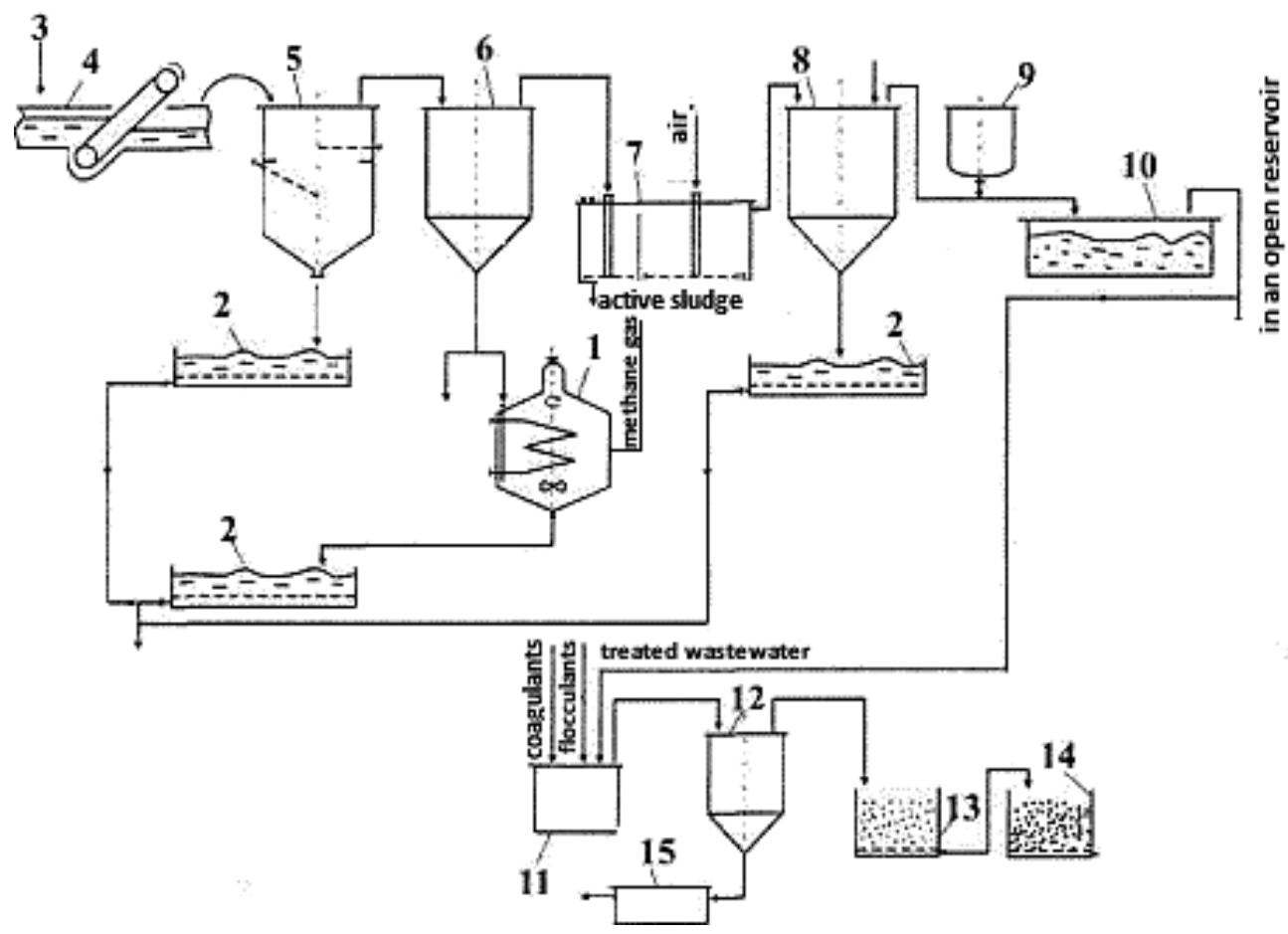

Fig. 1. Schematic diagram of mechanical, biological and chemical wastewater treatment:

1 - methane tank; 2 - silt sites; 3 - wastewater; 4 - lattice; 5 - sand trap; 6 - primary settling tank; 7 - bioreactor (aeration tank with biofilm); 8 - secondary settling tank; 9 - capacity for chlorination; 10 - contact tank; 11 - capacity for flocculation and coagulation; 12 - settling tank; 13 - sand filter; 14 - filter with activated carbon; 15 - sludge thickener [11]

During methane fermentation of alcohol bard (4.2\% SR) from 1 volume of fermentation liquid 22 volumes of gas, $2.5 \%$ of acid are formed $(0.46 \%$ of formic acid, $0.79 \%$ of acetic acid, $0.86 \%$ propionic, $0.39 \%$ oil, etc.) [8].

Due to the formation of a large volume of postalcohol bard (12-15 $\mathrm{dm}^{3}$ per $1 \mathrm{dm} 3$ of alcohol), simple methods of its utilization, such as cleaning in the filtration fields, the use as raw feed for cattle, fermentation, do not solve the problem completely.

Since bard has a fairly high humidity (90-95\%), the use of physical and chemical methods, namely drying to get dry feed DDGS, requires expensive equipment and high energy consumption. Cultivation of feed yeast biomass, methods of aerobic and anaerobic fermentation also have several disadvantages (formation of culture fluid, swelling of activated sludge, the inability of the system to reduce high $\mathrm{BOD}$ or $\mathrm{COD}$, which requires high-quality integrated solutions).
Cultivation of feed yeast biomass on PSB requires the installation of additional facilities for purification of culture fluid. To dispose PSB by anaerobic digestion, it is necessary to pre-treat it (separation of liquid and solid phases, ozonation, etc.) in order to provide additional substances to stabilize the $\mathrm{pH}$ and nutrients, which increase the cost of the process.

\section{Results of the investigation monitoring}

Examples of methods used to treat wastewater from the alcohol industry are adsorption, wet oxidation, ozone treatment and ion exchange, removal of chromophores using hydrogenation biological batch reactors, and colour (adsorbed organic halogens) removal by advanced oxidation processes. There are several ways to remove the colour from the industrial wastewater of distilleries. It is difficult to break down melanoidins by microorganisms. Various disadvantages of the above methods are overcome by the method of electrocoagulation. 
Therefore, wastewater from wastewater treatment systems still contains a high content of colour, melanoidins and COD.

The energy consumption required for wastewater treatment in the food industry is from 10 to $15 \%$ of total energy consumption. It is mainly used in aerobic treatment using oxidized organic compounds. At the same time, anaerobic methods of methane fermentation provide biogas with a methane content of 50 to $70 \%$, thus saving electricity compared to aerobic treatment methods.

Wastewater treatment technology in France. In France, 15 food industry enterprises are equipped with anaerobic wastewater treatment systems with organic contaminants. They use methane tanks with a capacity of 25 to 5.000 cubic meters. The world's largest methane tank operates on the principle of an anaerobic filter and has a capacity of 13 thousand cubic meters (Puerto Rico, rum plant).

The method of methanogenic wastewater fermentation is appropriate in the food industry due to the high concentration of contaminants in insignificant amounts of water, the soluble nature of organic contaminants, and the favourable temperature of wastewater $\left(30-35^{\circ} \mathrm{C}\right)$.

India is the largest producer of ethanol in Asia. Most distilleries in India use the anaerobic blanket reactor or its variants with subsequent settling / filters and aerobic treatment processes. This process is able to remove approximately $70 \%$ of COD and $80-90 \%$ of BOD. Wastewater from settling tanks / filters is called effluent biodigrant (BDE). BDE still contains very high levels of COD and BOD. This BDE is further treated aerobically. Although large plants around the world use complex treatment technologies, including physical, chemical and biological methods, small enterprises (plants) suffer from the lack of proper treatment systems due to financial constraints.

Analyzing the research of M. Potapova published in the article "Modern methods of processing and disposal of grain post-alcohol bard" we see that one of the promising methods of PSB utilization is aerobic fermentation. It has been argued that the use of cofermentation of the raw bard with bird droppings allows: to balance the nutrients, to bring the $\mathrm{pH}$ to the required for the process of methanogenesis, to achieve the desired ratio $\mathrm{C}: \mathrm{N}$. Under the conditions of cofermentation, a biogas yield of $265 \mathrm{~cm}^{3} / \mathrm{g}$ COP with a methane content of $72 \pm 2 \%$ is achieved.

It is planned to develop a mathematical model for the control of the technological process of obtaining biogas from post-grain bard depending on environmental conditions and the ratio of PSB: manure [2].
Analyzing the activity of Ukrspyrt State Enterprise, we have found that one of the products of the industry is bioethanol dehydrated, denatured, which is used for the production of gasoline, biofuels, ethyl tert-butyl ether, functional additives and additives to motor fuel. Bioethanol dehydrated is used as a component of automotive fuel for vehicles with petrol engines, which meets the requirements of EN 228 and is used for mixing in any quantities.

The organization of production of alternative motor fuel with bioethanol content allows the use of environmentally friendly component in motor fuel, which significantly reduces emissions of toxic substances, reduces dependence on energy imports, and improves the overall environmental situation in the country [9].

Currently, Ukrspyrt produces 150 thousand tons of bioethanol per year and carries out the reconstruction of enterprises, which will provide the Ukrainian market with this product. It is known that 15 distilleries are ready to produce biofuels. And with the beginning of full-scale production of bioethanol, Ukraine can establish exports of this product [12].

However, modern bioethanol production also requires wastewater disposal.

\section{Conclusions}

Increasing its capacity, the alcohol industry enhances the volume of waste, including the volume of wastewater that needs to be effectively treated before being released into the environment.

At the factories of the alcohol industry, basically all wastewater is treated at the factory treatment facilities (stations). The methods of wastewater treatment are necessary before transferring wastewater to biochemical treatment plants, before the discharge into reservoirs, or before regeneration in the circulating water supply system of the plant.

Biological methods of purification from organic substances play an important role in the enterprises of the alcohol industry. These methods are based on the use of microorganisms that convert organic compounds into nutrients and energy sources. Organic compounds decompose due to oxidation by anaerobic purification.

The analysis of wastewater is required to determine the method of treatment, the possibility of release into water bodies, the presence of valuable or toxic impurities.

Effective modern methods can clean wastewater from organic pollution by $85-95 \%$. They have only a small amount of surfactants, dissolved mineral salts, and other compounds.

Oxygen-free wastewater treatment in methane tanks is widely used in the food industry to produce energy biogas and bioorganic fertilizers (activated sludge). 
One of the most effective environmental directions of the alcohol industry is the introduction of the set of measures that will ensure the production of alcohol and its by-products with the lowest content of harmful substances, and prevent the violation of ecological balance in the environment, which is realized by the development and implementation of the latest environmentally friendly technologies for the production and disposal of its waste.

\section{References}

[1] Shved O. and Novikov V.: Ekolohichna biotekhnolohiya. chast.1, L'viv 2011, 250. (in Ukrain).

[2] Holub, N. and Potapova, M.: InnovBiosystBioeng, 2018, 2 (2), 125-134.
[3] Mel'nychuk O.: Ekonomika i derzhava, 2012. No. 2, 15-21.

[4] Zhonler I. V.: Ahroperspektyva, 2012, No. 8, 27-35.

[5] Elektronnyy resurs [https://er.nau.edu.ua/handle/NAU/ 38570]/

[6] Tymchak V. S.: Ekonomika APK, 2016, No. 10, 102-109.

[7] Zinchuk T. O.: Orhanichne Vyrobnytstva I Prodovol'cha Bezpeka, Zhytomyr, Polissya, 2014, 103-108.

[8] Elektronnyy resurs [ http://www.ukrstat.gov.ua].

[9] Elektronnyy resurs [ http://www.ukrspirt.com].

[10] Elektronnyy resurs [ http://zik.ua] rezhym dostupu.

[11] Mel'nychenko T. I. and Kadoshnikov V. M. and Zhebrovs'ka K. I. and Petrenko O. D. and Puhach O. V.: Hihiyena naselenykh mists'. No. 68, Ukrain, Kyyiv, 2018, 77

[12] Elektronnyy resurs [https://zakon.rada.gov.ua/laws/ show/z0403-02].

[13] V. O. Marynchenko: Tekhnolohiya spyrtu, Kyyiv NUKHT, 2003, 495. 